\title{
Quercetin oxidation by horseradish peroxidase: the effect of UV-B irradiation
}

\author{
Saša R. Savić, Jelena S. Stanojević, Dejan Z. Marković, Živomir B. Petronijević \\ University of Niš, Faculty of Technology, Leskovac, Serbia
}

\begin{abstract}
Horseradish peroxidase (HRP), a highly investigated member of the peroxidase family, has been known - among many other biological activities - to catalyze the oxidation of flavonoids and phenolic substrates overall, quercetin among them. On the other hand, quercetin is very well known for its expressed antioxidant activities, which in the case of UV external radiation can be expressed partly in a preventive manner: quercetin is an excellent UV-absorber. Therefore, the aim of this investigation was to study quercetin oxidation by HRP in phosphate buffer, under conditions of UV-stress, i.e. continuous, prolonged UV-B irradiation. The results show that while UV-B irradiation had definitely affected the activity of $\mathrm{HRP}$, and the overal rate of quercetin oxidation by HRP, it had probably very little effect on it for longer UV-B-irradiation periods (>30 $\mathrm{min}$ ).
\end{abstract}

Keywords: quercetin, peroxidase, UV-B radiation, kinetics, oxidation.

\section{SCIENTIFIC PAPER}

UDC 577.972:577.152.1:54:66

Hem. Ind. 67 (3) 411-418 (2013)

doi: 10.2298/HEMIND120607093S

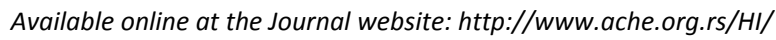

Peroxidases are enzymes that are widely distributed in eukaryotes and prokaryotes, and have a pivotal role in biology [1]. Most of peroxidases are hemoproteins, which contain ferriprotoporphyrin IX as the prosthetic group. The family of peroxidases includes plant ascorbate peroxidases, yeast cytochrome c peroxidase, the mammalian haloperoxidases (myeloperoxidase and lactoperoxidase), fungal peroxidases and other plant peroxidases [2,3].

Horseradish peroxidase (HRP, EC 1.11.1.7.) is a wellknown and highly investigated member of the peroxidase family that catalyzes the oxidation of flavornoids and phenolic substrates to the free phenoxyl or semiquinone radicals [1-2,4-7]. Previous studies have shown that the oxidation process of phenolic compounds can be considered as a modified type of pingpong kinetics $[8,9]$. HRP exhibits wide substrate specificity to donor hydrogens, and recently attention has been focused on polyphenols with complex structures $[1,2,8]$, such as flavonoids.

Flavonoids are a large group of polyphenols which are widely distributed in plants, vegetables, fruit juices, and a variety of beverages (tea, coffee, wines, and fruit drinks) [10-15]. Many experimental studies have demonstrated that they possess numerous biological and pharmacological effects including antioxidant, antimutagenic, anticarcinogenic, antiulcer, probiotic, antimicrobial, antiallergic, antiviral and antiinflammatory properties $[10-12,14,16]$. Because of its ubiquitous nature, quercetin $\left(3,3^{\prime}, 4^{\prime}, 5,7\right.$-pentahydroxyflavone) is

Correspondence: Ž.B. Petronijević, University of Niš, Faculty of Technology, Bulevar oslobođenja 124, 16000 Leskovac, Serbia.

E-mail: zpetronijevic@yahoo.com

Paper received: 7 June, 2012

Paper accepted: 22 August, 2012 the most studied of the dietary flavonoids and one of the most abundant plant-derived polyphenols widely consumed in a human diet [17-26]. Quercetin (Figure 1 ), containing the $3^{\prime}, 4^{\prime}$-dihydroxy structure of the $B$ ring (catechol $B$ ring), is known to possess a high antioxidant ability expressed through scavenging of free radicals (a "chain-breaking role"). It has a strong antioxidant effect against lipid peroxidation in phospholipid bilayers and in human low-density lipoprotein [13,21,27-28]. However, when lipid peroxidation chain reaction is initiated by UV-radiation then another quercetin antioxidant ability takes place. Since it is a strong UV-absorber, it can react as a preventive antioxidant by absorbing incident UV-radiation, therefore reducing initiation step of the LP chain mechanism, i.e., formation of reactive oxygen species (ROS) [29]. The UV energy absorbed by quercetin may be dissipated as heat [30] or converted into decomposition products [31]. The UV-irradiation of flavonoids in solutions and in liposome systems in vitro, as well as in vivo, results in their irreversible breakdown, accompanied by the appearance of a number of decomposition products $[32,33]$. In a recently published paper, by using HPLC techniques to analyse UV-B (300 nm) and UV-C (254 nm) irradiated quercetin in methanol solution, we have detected at least four decomposition products, some of them belonging to quinones family, and established the formation kinetics [34]. Based on this, we have explored the relationship between quercetin stability to UV-irradiation and it has antioxidant ability (under the same UV-irradiation regime) by comparing it to the one of its flavonoid counterpart, rutin, with glycoside residue at the 3-position [35].

The 3-position (at the ring C) makes the crucial difference between quercetin and rutin [31]. Because 
quercetin has a free hydroxyl group at the 3-position, this compound can also act as an inhibitor of the tyrosinase [36,37]. Thus, this molecule is simultaneously a substrate and an inhibitor, depending on the way in which it binds to the copper atoms of the active site. Since UV-irradiation evidently affects quercetin structure, it would be interesting to see how it would affect quercetin-involving enzymatic oxidation reactions.

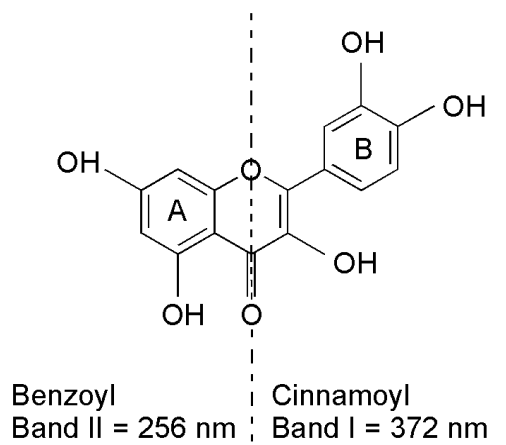

Figure 1. Quercetin structure with the indicated (benzoyl and cinnamoyl) parts contributing to spectral band I and II [20].

Previous studies have shown that the enzymatic oxidation of quercetin primarily produces quinones, which can react with various nucleophilic agents building adducts [36]. We have already investigated the oxidation of quercetin by HRP in the presence of L-cysteine and possible related mechanisms (unpublished). In the extension, the objective of this work is to study possible effects that continuous, prolonged UV-B-irradiation might have on oxidation of quercetin by HRP.

\section{EXPERIMENTAL}

\section{Chemicals and preparation of sample solutions}

Quercetin (Sigma-Aldrich) of the highest quality available (98\%) was used without purification. A $10 \mathrm{mM}$ stock solution of quercetin was prepared in methanol (HPLC grade, J.T.Baker) immediately before the experiments. For all experiments, freshly prepared solutions of quercetin were made by dilution of the appropriate amount of the stock solution with phosphate buffer at $\mathrm{pH} 7.4$.

Horseradish peroxidase $(298 \mathrm{U} / \mathrm{mg}$; using pyrogallol) was purchased from Sigma-Aldrich (Germany). A $2 \mu \mathrm{M}$ stock solution of HRP was prepared by dissolving the $0.34 \mathrm{mg}$ of the solid HRP in $10 \mathrm{ml}$ of cold $50 \mathrm{mM}$ phosphate buffer, $\mathrm{pH}$ 6.0. The enzyme concentration was calculated using $\varepsilon_{403}=102.0 \mathrm{mM}^{-1} \mathrm{~cm}^{-1}$.

\section{Spectrophotometric assays}

\section{Quercetin degradation}

Kinetic assays were carried out by tracing the disappearance of quercetin (at $380 \mathrm{~nm}$ ) in the reaction medium on Varian Cary-100 spectrophotometer equipped with UV-Winlab software in quartz cuvettes dimensions, $1 \mathrm{~cm} \times 1 \mathrm{~cm} \times 4.5 \mathrm{~cm}$. The measured samples consisted of $1.6 \mathrm{mM}$ quercetin only, quercertin with 0.1 $\mathrm{mM} \mathrm{H}_{2} \mathrm{O}_{2}$, quercetin with $8 \mathrm{nM} \mathrm{HRP}$, and finally the reaction mixture (quercetin, $\mathrm{H}_{2} \mathrm{O}_{2}$ and $\mathrm{HRP}$ ), all in 100 $\mathrm{mM}$ phosphate buffer ( $\mathrm{pH} 7.4$ ), and all irradiated in 2.5 $\mathrm{ml}$ volumes with UV-B at increasing time periods (10-60 min).

\section{Determination of reaction rate}

To determine the overall reaction rate, aliquots from HRP solution in $50 \mathrm{mM}$ phosphate buffer ( $\mathrm{pH}$ 6.0) were synchronously irradiated with the above samples under the same irradiation conditions, and then subjected to a series of consecutive absorbance measurements at $\lambda_{\max }=380 \mathrm{~nm}$ (corresponding to increasing irradiation periods) every $10 \mathrm{~s}$, for a period of $120 \mathrm{~s}$. All measurements were performed at temperature of 20 ${ }^{\circ} \mathrm{C}$. The blank was represented by $100 \mathrm{mM}$ phosphate buffer $\mathrm{pH} 7.4$.

Enzymatic reaction was performed by mixing irradiated HRP solution with non-irradiated quercetin phosphate buffer ( $\mathrm{pH}$ 7.4) solution, followed by subsequent addition of $50 \mu \mathrm{l} 10 \mathrm{mM}$ hydrogen peroxide solution; the reaction was carried out by vigorous vortexing.

Determination of the proportion of enzymatic reaction in the overall reaction was done by comparing the reaction rate in the presence and absence of the enzyme.

\section{Activity measurements}

Peroxidase activity was determined by Soysal and Söylemez [38], with slight modification. A $2.1 \mathrm{ml}$ of 100 $\mathrm{mM}$ acetate buffer ( $\mathrm{pH} \mathrm{6)}$ was measured followed by addition of $0.5 \mathrm{ml} 8.8 \mathrm{mM} \mathrm{H}_{2} \mathrm{O}_{2}, 0.2 \mathrm{ml}$ of $0.125 \%$ solution of $o$-dianisidine in methanol; the mixture was vigorously vortexed, and finally $0.2 \mathrm{ml}$ solution of the irradiated HRP was added. Change of absorbance was recorded as a function of time at $460 \mathrm{~nm}$ and activity of HRP was calculated by using following equation:

$A[\mathrm{U} / \mathrm{ml}]=(R / \varepsilon) \operatorname{tg} \alpha$

where $\operatorname{tg} \alpha$ is a slope, $R$ - ratio of the total volume of the reaction mixture and the enzyme volume, $\varepsilon-$ molar extinction coefficient $\left(\varepsilon_{460}=11.3 \mathrm{mM}^{-1} \mathrm{~cm}^{-1}\right)$.

The reference blank contained all reagents except the hydrogen peroxide, which was replaced by aqua destillata.

One unit of peroxidase activity was defined as the amount of enzyme that transformed $1 \mu \mathrm{mol}$ of $o$-dianisidine per min.

\section{UV-irradiation}

Continuous irradiation of the samples was performed in a cylindrical photochemical reactor "Rayonnet", 
with 7 symmetricaly placed lamps with emission maxi$\mathrm{ma}$ at $300 \mathrm{~nm}$ (UV-B). The samples were irradiated in quartz cuvettes $(1 \mathrm{~cm} \times 1 \mathrm{~cm} \times 4.5 \mathrm{~cm})$ placed on a rotating circular holder. The total measured energy flux is about $10.5 \mathrm{~W} / \mathrm{m}^{2}$ at $10 \mathrm{~cm}$ distance from the lamps.

\section{RESULTS AND DISCUSSION}

UV-B radiation effects on plants have been well documented. Reduced photosynthesis, decreased protein synthesis and production of ROS species are among them [39-44]. However, there are other types of abiotic and biotic stresses that can also produce ROS, such as singlet oxygen, hydrogen peroxide, and hydroxyl radicals, in plants [41-44]. Plants have developed several defense systems against ROS-induced harmful effects. Peroxidase, as a member of a group of antioxidant enzymes, plays an important role by converting hydrogen peroxide to water molecules. It is known that HRP usually occurs in multiple molecular forms (isoenzymes), but their function and regulation remain largely unknown. On the other hand, as a part of an entire answer against UV-radiation inducing effects, plants react preventively through a synthesis of UV-absorbing, protective pigments, such as flavonoids [45-47].

The absorption spectrum of quercetin features two major peaks, one belonging to the band $I$ as a result of absorption of the catechol B-ring in UV-A range, between 360 and $370 \mathrm{~nm}\left(\lambda_{\max }=365 \mathrm{~nm}, \varepsilon=28400\right.$ $\left.\mathrm{M}^{-1} \mathrm{~cm}^{-1}\right)$, and the other one, belonging to band II as a result of benzoyl A-C system in UV-C range, around 260 $\mathrm{nm}\left(\lambda_{\max }=256 \mathrm{~nm}, \varepsilon=28.300 \mathrm{M}^{-1} \mathrm{~cm}^{-1}\right)$. When quercetin is irradiated with continuous prolonged UV-radiation, its stability is affected. In order to estimate it, quercetin stability toward UV-irradiation from the three belonging sub-ranges (UV-A, UV-B and UV-C) was compared to the one of its flavonoid counterpart, rutin, under the same irradiation conditions [35]. It was found that the stability of both flavonoids towards UVirradiation is highly affected by the incident photons energy input (declining from UV-A via UV-B to UV-C), but inside the same UV-sub-range quercetin was found much more sensitive compared to rutin (i.e., its degradation was faster), which was attributed to the presence of the very reactive 3-OH position in the C-ring of quercetin [31,35]. The same result has been confirmed in the subsequent paper by using HPLC to analyse irradiated quercetin and rutin solutions in methanol [34]; at least four different quercetin-originating UV-B\&C induced products have been clearly recorded on the corresponding chromatograms (with $A_{\max }$ values in 295-300 nm range) and the anticipated structures have been proposed, at least two of them implying the opening of the C-ring [29,34].
A question emerges on the relevancy of these facts (UV-induced structural changes in quercetin structure) when quercetin is subjected to oxidation by HRP under condition of UV-sttress. To answer this, quercetin was irradiated with the increasing UV-B irradiation time periods in the same phosphate buffer mediums, in the absence and presence of HRP. The spectral changes are shown in Figure 2 ( $A, B$ - left), while the related quercetin degradation plots expressing first order type of behavior (including some points scattering) is shown in Figure 2 ( $A, B$ - right). The changes in the quercetin spectra, expressed through decrease of $A_{\max }$ values of both major bands $\left(A_{380 \mathrm{~nm}}\right.$ and $A_{267 \mathrm{~nm}}$, both in the absence, as well as in the presence of HRP) clearly prove that quercetin undergoes degradation with the increase of UV-B irradiation periods, while a synchronous rise of absorbance with $A_{\max }$ at $329 \mathrm{~nm}$ was detected; the peak position $\left(\lambda_{\max }=329 \mathrm{~nm}\right)$ is significantly red-shifted compared to the one found in our previous paper when quercetin itself was irradiated in methanol $\left(\lambda_{\max }=295 \mathrm{~nm}\right)$ [34]. This shift can certainly be attributed to the change of medium (phosphate buffer, $\mathrm{pH}$ 7.4, versus $\mathrm{MeOH}$ ), since it is already known that quercetin spectrum itself is very much affected by change of $\mathrm{pH}$ in the range of 2-12 [48]. However, when quercetin is oxidized by myeloperoxidase in $50 \mathrm{mM}$ phosphate buffer ( $\mathrm{pH}$ 6.5) in the presence of $\mathrm{H}_{2} \mathrm{O}_{2}$ and in the absence of any radiation, the detected product had $A_{\max }$ at $336 \mathrm{~nm}$ [49], suggesting some possible correlation between the two (UV-induced and enzymatic) mechanisms. Awad et al. [13] have listed structures of compunds obtained as a result of various flavonoids oxidation by different types of peroxidases with $\mathrm{H}_{2} \mathrm{O}_{2}$. Most of them have been created through C-ring opening preceding final structures formation (benzoic acid derivatives - like the ones obtained by UV-oxidation of quercetin in methanol [29]). On the other hand, the calculated quercetin degradation rate constants (from the slopes of the respected plots, Figure $2(A, B-$ right)) are $\mathbf{0 . 0 2 0}$, for quercetin itself, and 0.022 for quercetin in the presence of HRP. Evidently, quercetin degrades at very similar rate in the absence and the presence of HRP (the difference is roughly about 10\%). Based on this fact, a question emerges if quercetin oxidation by HRP is affected at all by a prolonged, continuous UVirradiation.

Part of the answer might come from investigation of possible change of HRP activity as a result of UV-B irradiation. Unlike several previous in vivo studies [50], this report represents in vitro study of UV-B irradiation effects on HRP activity.

Temporal absorbance changes of the added substrate during measurements of activity of irradiated HRP are shown in Figure 3. The results indicate that the activity of HRP decreases with increasing periods of UV-B 

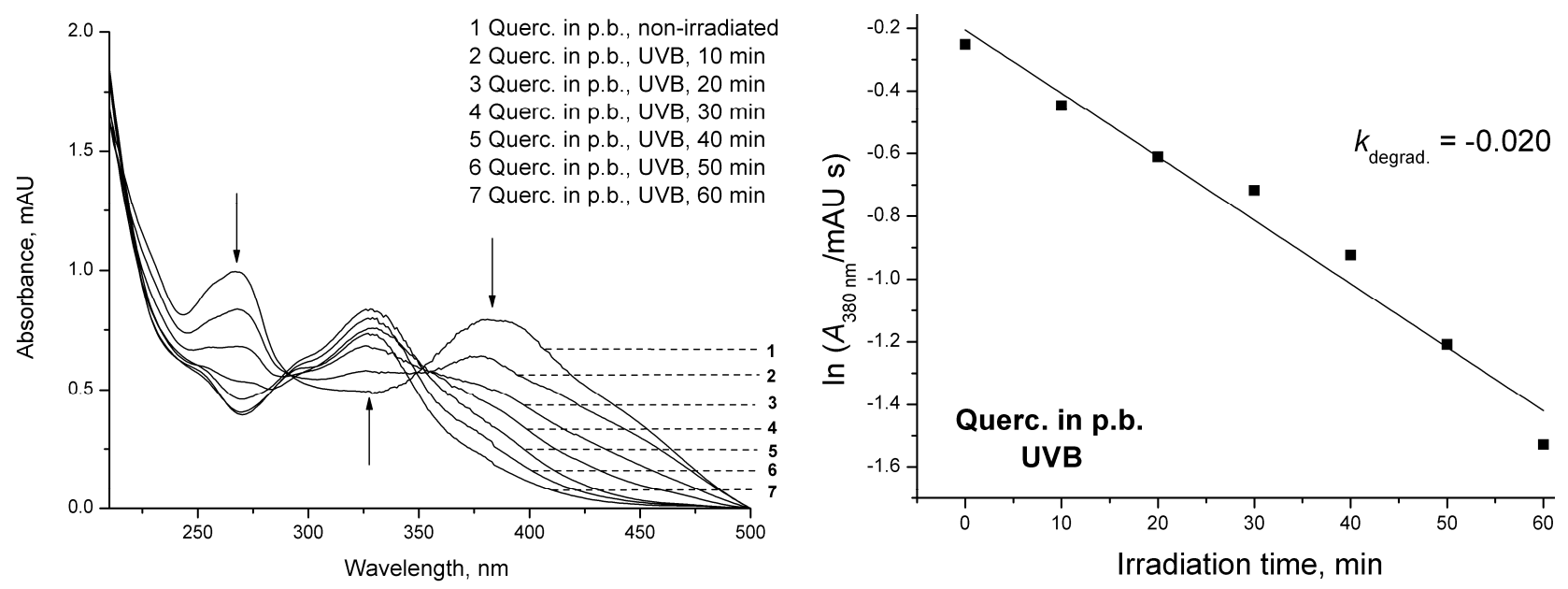

(A)
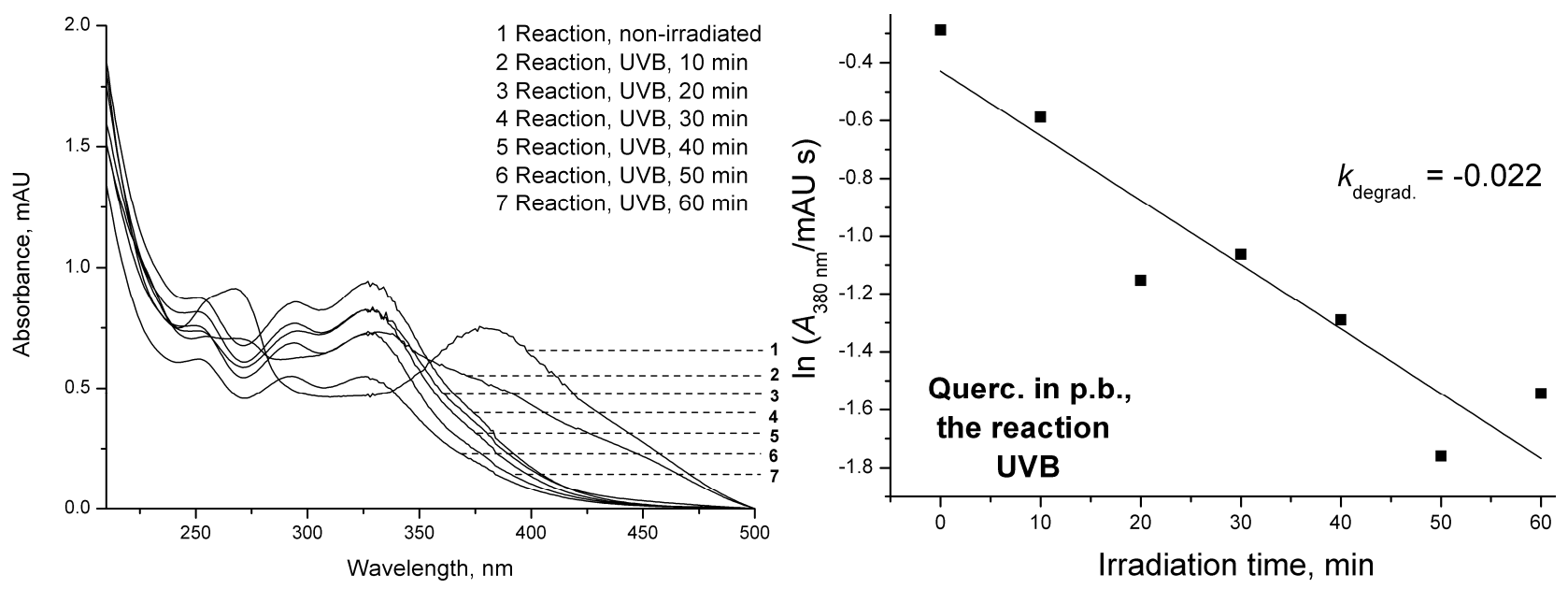

(B)

Figure 2. Changes in the absorption spectra of quercetin in phosphate buffer only and in the reaction mixture, irradiated with continuous UV-B irradiation ( $A, B$, left, respectively). The exposure time periods were displayed on the graphs, and the arrows show the changes direction: down ( $\downarrow)$, in the case of quercetin, and up ( $\uparrow)$ in the case of the possible degradation products formation. Kinetic In plots of UV-B induced quercetin only ( $A$, right), as well as in the reaction mixture (B, right), detected as decrease of the band I absorbance (recorded at $380 \mathrm{~nm}$ ), as a function of UV-B irradiation: In $A_{380 \mathrm{~nm}}$ as a function $t_{i r r}$. The plots show linear fitting, with $R^{2} \approx 0.85(B)$ and $R^{2} \approx 0.97(A)$. Corresponding rate constants calculated from the slopes of the linear plots are displayed on the graphs.

irradiation (of HRP), which is in accordance with already published results [51]. HRP activity falls to $50 \%$ of the initial activity after 20 min UV-B irradiation (Table 1). Mechanism of HRP inactivation takes place most probably through change of some amino acid residues; the increasing irradiation doses leads to disorganization of enzyme structure $[1,51]$.

Figure 4 shows the change of the rate of quercetin oxidation by increasingly irradiated HRP. The nonirradiation case is shown in the increment, indicating that this reaction is mostly enzymatic; the minor, nonenzymatic reaction makes $10 \%$ of the total reaction. Table 2 (presenting the rate reaction values) suggests that the increased irradiation periods of HRP lead to reducement of the overall rate reaction, which looks compatibile with irradiated-HRP activity results.
However, the compatibility is not complete: it does exist until $30 \mathrm{~min}$ of irradiation (Figure 4), whereas for UV-B irradiation periods longer than $30 \mathrm{~min}$ the values of quercetin oxidation rates (for 30, 40, 50 and 60 min irradiated HRP) remain the same as in the case of HRP absence, i.e., in the non-enzymatic case (Figure 4 - increment, the upper plot). Since HRP expressed some "survived" activity after 60 min of UV-B irradiation, this non-compatibility can be explained by an additional quercetin role: it might also act as an HRP inhibitor depending on a binding mode [36]. In fact, previous studies have shown that quercetin could bind to HRP by occupying the enzyme active positions by its hyd roxyl groups leading to a block of the HRP heme group [1]. 


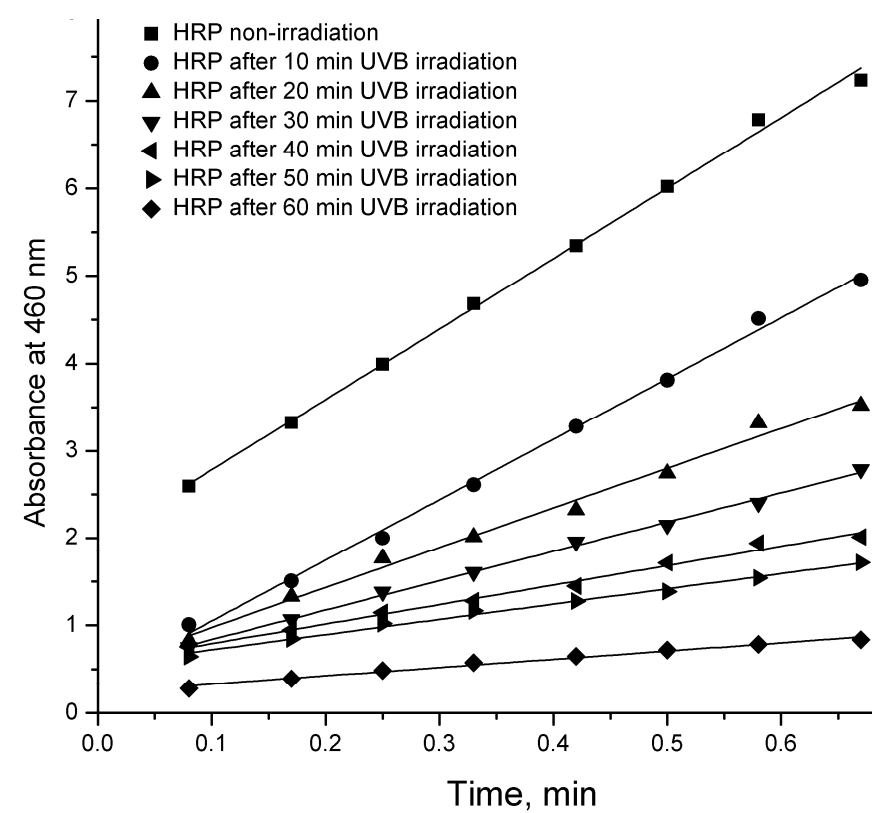

Figure 3. Change of activity of HRP as a result of UV-B irradiation.

Table 1. Change of activity of HRP as a result of UV-B irradiation

\begin{tabular}{lcc}
\hline Time, $\min$ & $U / \mathrm{ml}$ & $\%$ \\
\hline 0 & 17.803 & 100.00 \\
10 & 15.365 & 86.31 \\
20 & 10.095 & 56.74 \\
30 & 7.429 & 41.71 \\
40 & 4.915 & 27.60 \\
50 & 3.838 & 21.56 \\
60 & 2.081 & 11.73 \\
\hline
\end{tabular}

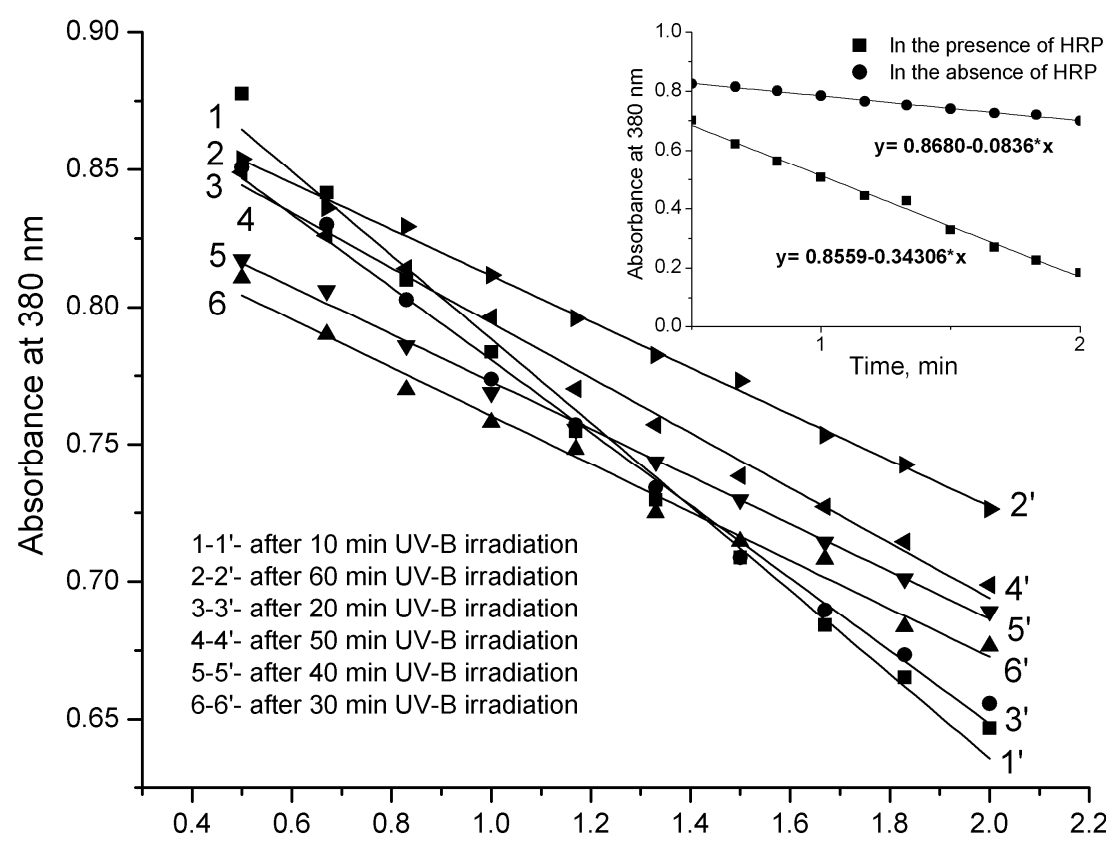

Time, $\min$

Figure 4. Change of overall reaction rate (oxidation of quercetin by HRP) as a result of UV-B irradiation. The increment shows the non-irradiation case in the presence and in the absence of HRP, recorded at $380 \mathrm{~nm}$. 
Table 2. Change of reaction rates: overall, and the enzymatic parts, separately, as a result of increasing UVB irradiation periods

\begin{tabular}{|c|c|c|c|}
\hline \multirow{2}{*}{ Time of UV-B irradiation, min } & \multirow{2}{*}{ Rate of overall reaction, $\Delta A_{380} / \min$} & \multicolumn{2}{|c|}{ Change of the rate of the enzymatic reaction } \\
\hline & & $\Delta A_{380} / \min$ & $\%$ \\
\hline 0 & 0.343 & 0.260 & 100.00 \\
\hline 10 & 0.152 & 0.069 & 26.54 \\
\hline 20 & 0.132 & 0.049 & 18.85 \\
\hline 30 & 0.087 & 0.004 & 1.54 \\
\hline 40 & 0.086 & 0.003 & 1.15 \\
\hline 50 & 0.100 & 0.017 & 6.54 \\
\hline 60 & 0.084 & 0.001 & 0.38 \\
\hline
\end{tabular}

\section{CONCLUSION}

In conclusion, it seems that while UV-B irradiation has definitely affected the activity of HRP and the overal rate of quercetin oxidation by HRP, it probably had very little effect on it for UV-B irradiation periods longer than $30 \mathrm{~min}$. In other words, after $30 \mathrm{~min}$ of continuous irradiation it seems that the reaction followed the non-enzymatic pattern.

\section{Acknowledgements}

This work was supported by the Ministry of Education, Science and Technological Development of the Republic of Serbia under Project No.TR-34012 and OI172044.

\section{REFERENCES}

[1] L.M. Kabeya, A.A. de Marchi, A. Kanashiro, N.P. Lopes, C.H.T.P. da Silva, M.T. Pupo, Y.M. Lucisano-Valim, Inhibition of horseradish peroxidase catalytic activity by new 3-phenylcoumarin derivatives: Synthesis and structure-activity relationships, Bioorgan. Med. Chem. 15 (2007) 1516-1524.

[2] L. Pourcel, J. Routaboul, V. Cheynier, L. Lepiniec, I. Debeaujon, Flavonoid oxidation in plants: From biochemical properties to physiological functions, Trends Plant Sci. 12 (2006) 29-36.

[3] A. Osman, D.P. Makris, P. Kefalas, Investigation on biocatalytic properties of a peroxidase-active homogenate from onion solid wastes: An insight into quercetin oxidation mechanism, Process Biochem. 43 (2008) 861$-867$.

[4] W. Schreiber, Action of horseradish peroxidase upon some flavones, FEBS Lett. 41 (1974) 50-52.

[5] T. Miura, S. Muraoka, Y. Fujimoto, Inactivation of creatine kinase induced by quercetin with horseradish peroxidase and hydrogen peroxide: Pro-oxidative and antioxidative actions of quercetin, Food Chem. Toxicol. $\mathbf{4 1}$ (2003) 759-765.

[6] L. Vachoud, T. Chen, G.F. Payne, R. Vazquez-Duhalt, Peroxidase catalyzed grafting of gallate esters onto the polysaccharide chitosan, Enzyme Microb. Technol. 29 (2001) 380-385.
[7] E. Miller, P. Schreier, Studies on flavonol degradation by peroxidase (donor: $\mathrm{H}_{2} \mathrm{O}_{2}$-oxidoreductase, EC 1.11.1.7). 1. Kaempferol, Food Chem. 17 (1985) 143-154.

[8] Y. Wu, K.E. Taylor, N. Biswas, J.K. Bewtra, A model for the protective effect of additives on the activity of horseradish peroxidase in the removal of phenol, Enzyme Microb. Technol. 22 (1998) 315-322.

[9] H.B. Dunford, in: J. Everse, K.E. Everse, M.B. Grisham (Eds.), Peroxidases in Chemistry and Biology, CRC Press, Boca Raton, Florida, 1991, p. 225.

[10] D. Procházková, I. Boušová, N. Wilhelmová, Antioxidant and prooxidant properties of flavonoids, Fitoterapia $\mathbf{8 2}$ (2011) 513-523.

[11] G. Galati, M.Y. Moridani, T.S. Chan, P.J. O'Brein, Peroxidative metabolism of apigenin and naringenin versus luteolin and quercetin: glutathione oxidation and conjugation, Free Radical Biol. Med. 30 (2001) 370-382.

[12] H.M. Awad, M.G. Boersma, S. Boeren, H. van Der Woude, J. van Zanden, P.J. van Bladeren, J. Vervoort, I.M.C.M. Rietjens, Identification of o-quinone/quinone methide metabolites of quercetin in a cellular in vitro system, FEBS Lett. 520 (2002) 30-34.

[13] H.M. Awad, M.G. Boersma, J. Vervoort, I.M.C.M. Rietjens, Peroxidase-catalyzed formation of quercetin quinone methide \pm glutathione adducts, Arch. Biochem. Biophys. 378 (2000) 224-233.

[14] J.E. Chung, M. Kurisawa, Y. Tachibana, H. Uyama, S. Kobayashi, Enzymatic synthesis and antioxidant property of poly(allylamine)-catechin conjugate, Chem. Lett. 32 (2003) 620-621.

[15] G. Dehghan, J.E.N. Dolatabadi, A. Jouyban, K.A. Zeynali, S.M. Ahmadi, S. Kashanian, Spectroscopic studies on the interaction of quercetin-terbium(III) complex with calf thymus DNA, DNA Cell Biol. 30 (2011) 195-201.

[16] R.J. Nijveldt, E. van Nood, D.E. van Hoorn, P.G. Boelens, K. van Norren, P.A. van Leeuwen, Flavonoids: A review of probable mechanisms of action and potential applications, Am. J. Clin. Nutr. 74 (2001) 418-425.

[17] T. Andrade-Filho, T.C.S. Ribeiro, J. Del Nero, The UV-vis absorption spectrum of the flavonol quercetin in methanolic solution: A theoretical investigation, Eur. Phys. J., E (2009) 1-7.

[18] L. Yang, P. Li, Y. Gao, D. Wu, Qualitative observation of chemical change rate for quercetin in basic medium characterized by time resolved UV-VIS spectroscopy, J. Mol. Liq. 151 (2010) 134-137. 
[19] P. Ryan, M.J. Hynes, The kinetics and mechanisms of the reactions of iron(III) with quercetin and morin, J. Inorg. Biochem. 102 (2008) 127-136.

[20] S.B. Bukhari, S. Memon, M. Mahroof-Tahir, M.I. Bhanger, Synthesis, characterization and antioxidant activity copper-quercetin complex, Spectrochim. Acta, A 71 (2009) 1901-1906.

[21] J.P. Cornard, J.C. Merlin, Spectroscopic and structural study of complexes of quercetin with $\mathrm{Al}(\mathrm{III}), \mathrm{J}$. Inorg. Biochem. 92 (2002) 19-27.

[22] E.M. Cherviakovsky, D.A. Bolibrukh, A.V. Baranovsky, T.M. Vlasova, V.P. Kurchenko, A.A. Gilep, S.A. Usanov, Oxidative modification of quercetin by hemeproteins, Biochem. Biophys. Res. Commun. 342 (2006) 459-464.

[23] A. Gülşen, D.P. Makris, P. Kefalas, Biomimetic oxidation of quercetin: Isolation of a naturally occurring quercetin heterodimer and evaluation of its in vitro antioxidant properties, Food Res. Int. 40 (2007) 7-14.

[24] H. van der Woude, Mechanisms of toxic action of the flavonoid quercetin and its phase II metabolites. 1st ed., Thesis Wageningen University; Wageningen, 2006, p. 123.

[25] Y.H. Moon, J.H. Lee, D.Y. Jhon, W.J. Jun, S.S. Kang, J. Sim, H. Choi, J.H. Moon, D. Kim, Synthesis and characterization of novel quercetin- $\alpha$-D-glucopyranosides using glucansucrase from Leuconostoc mesenteroides, Enzyme Microb. Technol. 40 (2007) 1124-1129.

[26] G. Michels, G.R.M.M. Haenen, W. Wätjen, S. Rietjens, A. Bast, The thiol reactivity of the oxidation product of 3,5,7-trihydroxy-4H-chromen-4-one containing flavornoids, Toxicol. Lett. 151 (2004) 105-111.

[27] D.P. Makris, J.T. Rossiter, An investigation on structural aspects influencing product formation in enzymic and chemical oxidation of quercetin and related flavonols, Food Chem. 77 (2002) 177-185.

[28] A. Zhou, S. Kikandi, O.A. Sadik, Electrochemical degradation of quercetin: Isolation and structural elucidation of the degradation products, Electrochem. Commun. 9 (2007) 2246-2255.

[29] B.M. Fahlman, E.S. Krol, UVA and UVB radiation-induced oxidation products of quercetin, J. Photochem. Photobiol., B 97 (2009) 123-131.

[30] E. Falkovskaia, P.K. Sengupta, M. Kasha, Photophysical induction of dual fluorescence of quercetin and related hydroxyflavones upon intermolecular $\mathrm{H}$-bonding to solvent matrix, Chem. Phys. Lett. 297 (1998) 109-114.

[31] G.J. Smith, S.J. Thomsen, K.R. Markham, C. Andary, D. Cardon, The photostabilities of naturally occurring 5hydroxyflavones, flavonols, their glycosides and their aluminium complexes, J. Photochem. Photobiol. A: Chem. 136 (2000) 87-91.

[32] E.S.B. Ferreira, A. Quye, H. McNab, A.N. Hulme, Photooxidation products of quercetin and morin as markers for the characterization of natural flavonoid yellow dyes in ancient textiles, Dyes Hist. Archaeol. 18 (2002) 63-72.

[33] B.M. Fahlman, E.S. Krol, Inhibition of UVA and UVB radiation-induced lipid oxidation by quercetin, J. Agric. Food Chem. 57 (2009) 5301-5305.
[34] J.B. Zvezdanovic, J.S. Stanojevic, D.Z. Markovic, D.J. Cvetkovic, Irreversible UV-induced quercetin and rutin degradation in solution studied by UV spectrophotometry and HPLC chromatography, J. Serb. Chem. Soc. 77 (2012) 297-312.

[35] D. Cvetkovic, D. Markovic, D. Cvetkovic, B. Radovanovic, Effects of continuous UV irradiation on antioxidant activities of quercetin and rutin in solution in the presence of lecithin as the protective target, J. Serb. Chem. Soc. 76 (2011) 973-985.

[36] L.G. Fenoll, P.A. Garciäa-Ruiz, R. Varón, F. GarciäaCänovas, Kinetic study of the oxidation of quercetin by mushroom tyrosinase, J. Agric. Food Chem. 51 (2003) 7781-7787.

[37] Q. Chen, I. Kubo, Kinetics of mushroom tyrosinase inhibition by quercetin, J. Agric. Food Chem. 50 (2002) 4108-4112.

[38] Ç. Soysal, Z. Söylemez, Kinetics and inactivation of carrot peroxidase by heat treatment, J. Food Eng. 68 (2005) 349-356.

[39] F. Hollsy, Effects of ultraviolet radiation on plant cells, Micron 33 (2002) 179-197.

[40] S. Kaewsuksaeng, Y. Urano, S. Aiamla-or, M. Shigyo, N. Yamauchi, Effect of UV-B irradiation on chlorophylldegrading enzyme activities and postharvest quality in stored lime (Citrus latifoliaTan.) fruit, Postharvest Biol. Technol. 61 (2011) 124-130.

[41] H. Costa, S.M. Gallego, M.L. Tomaro, Effects of UV-B radiation onantioxidant defense system in sunflower cotyledons, Plant Sci. 162 (2002) 939-945.

[42] M. Rybus-Zając, J. Kubiś, Effect of UV-B radiation on antioxidative enzyme activity, Acta Biol. Cracov. Bot. 52 (2010) 97-102.

[43] J. He, X. Yue, R. Wang, Y. Zhang, Ethylene mediates UV$B$-induced stomatal closure via peroxidase-dependent hydrogen peroxide synthesis in Vicia faba L., J. Exp. Bot. (2010) 1-10.

[44] S. Aiamla-or, S. Kaewsuksaeng, M. Shigyo, N. Yamauchi, Impact of UV-B irradiation on chlorophyll degradation and chlorophyll-degrading enzyme activities in stored broccoli (Brassica oleracea L. Italica Group) florets, Food Chem. 120 (2010) 645-651.

[45] A. Strid, R.J. Porra, Alterations in pigment content in leaves of Pisum sativum after exposure to supplementary UV-B, Plant Cell Physiol. 33 (1992) 1015-1023.

[46] A. Strid, W.S. Chow, J.M. Anderson, UV-B damage and protection at the molecular level in plants, Photosynth. Res. 39 (1994) 475-489.

[47] E.M. Middleton, A.H. Teramura, The role of flavonol glycosides and carotenoids in protecting soybean from UB-B damage, Plant Physiol. 103 (1993) 741-752.

[48] T. Momic, J. Savic, U. Cernigoj, P. Trebse, V. Vasic, Protolytic equilibria and photodegradation of quercetin in aqueous solution, Collect. Czech. Chem. Commun. 72 (2007) 1447-1460.

[49] T. Momic, J. Savic, V. Vasic, Oxidation of quercetin by myeloperoxidase, Res. Lett. Phys. Chem. (2009) 1-4.

[50] G.G. Yannarelli, S.M. Gallego, M.L. Tomaro, Effect of UV$B$ radiation on the activity and isoforms of enzymes with 
peroxidase activity in sunflower cotyledons, Environ. Exp. Bot. 56 (2006) 174-181.

[51] M. Constantinovici, D. Oancea, T. Zaharescu, Gamma irradiation effect on the enzymatic activities of hor- seradish and apple peroxidases, Radiat. Phys. Chem. 78 (2009) 33-36.

\section{IZVOD}

\section{OKSIDACIJA KVERCETINA POMOĆU PEROKSIDAZE IZ RENA: EFEKAT UV-B ZRAČENJA}

Saša R. Savić, Jelena S. Stanojević, Dejan Z. Marković, Živomir B. Petronijević

\section{Univerzitet u Nišu, Tehnološki fakultet, Leskovac, Srbija}

(Naučni rad)

Peroksidaza iz rena (HRP) jedan je od najviše istraživanih enzima iz grupe peroksidaza, koji poseduje pored drugih bioloških aktivnosti i sposobnost da katalizuje oksidaciju mnogih flavonoida i fenolnih supstrata, između ostalog i kvercetina. Sa druge strane, poznato je da kvercetin poseduje izraženu antioksidativnu aktivnost, koja u slučaju UV zračenja može biti izražena delom i na preventivni način: kvercetin je odličan UV-absorber. Stoga je cilj ovog istraživanja bio da se ispita oksidacija kvercetina pomoću peroksidaze iz rena $u$ fosfatnom puferu pod uslovima UV-stresa, tj. pod dejstvom kontinualnog produženog UV-B ozračivanja. Rezultati pokazuju da definitivno, UV-B ozračivanje utiče na aktivnost HRP, kao i na ukupnu brzinu oksidacije kvercetina pomoću HRP, s tim da je uticaj na brzinu oksidacije (kvercetina) veoma mali nakon dužeg perioda UV-B ozračivanja (>30 $\min )$.
Ključne reči: Kvercetin • Peroksidaza • UV-B zračenje $\bullet$ Kinetika $\bullet$ Oksidacija 